Review article

\title{
MYCOBACTERIOSIS IN PIGS - AN UNDERRATED THREAT
}

\author{
POLAČEK Vladimir ${ }^{* *}$, ALEKSIĆ-KOVAČEVIĆ Sanja²
}

${ }^{1}$ Scientific Veterinary Institute Novi Sad, Novi Sad, Serbia;

${ }^{2}$ Faculty of Veterinary Medicine, University of Belgrade, Belgrade, Serbia

(Received 02 November; Accepted 30 November 2016)

\begin{abstract}
Although Mycobacterium avium subspecies are generally not considered food pathogens, the infections caused by these particular nontuberculous mycobacteria (NTM) can represent a serious threat to immunocompromised population. Additionally, infections with a member of Mycobacterium Avium Compex (MAC) can affect the efficiency of BCG vaccines used for the humans. In infected animals, M. avium may be present in different tissues without apparent clinical symptoms and macroscopic lesions. Veterinary meat inspection would then fail to recognize infected animals and such meat and meat products thereof could enter the human diet. The aim of this paper is also to analyze the current control policy in Europe according to infections of pigs with the members of MAC, and point out the risks for public health. By analyzing a large number of meat samples and other dietary nutrients, different groups of authors have provided evidence to support the hypothesis that M. avium is present in the everyday environment. Therefore, food as a source of infection with mycobacteria should not be ignored. The control of mycobacteria requires a better diagnostic approach, having in mind recent positive cases of $\mathrm{M}$. avium subspecies hominissuis (MAH) in an increasing number of exported pigs from EU countries to Serbia. The introduction of reliable diagnostic methods for MAH could result in decreasing the occurrence of infection in pigs, as well as in humans, having in mind that WHO reported 10 million new cases of tuberculosis-mycobacteriosis in the human population in 2015 with $21 \%$ of these cases occurring in immunocompromised individuals and children.
\end{abstract}

Key words: Mycobacterium avium subsp hominissuis, MAC, NTM

\section{INTRODUCTION}

Members of Mycobacterium avium complex (MAC) are ubiquitous organisms that are isolated from a variety of environmental sources, including water, soil, dust and aerosol, as well as from animals [1-2]. Important members of MAC for veterinary and human medicine include $M$. avium subsp avium (MAA), $M$. avium subsp hominissuis (MAH), M. avium subsp paratuberculosis (MAP) and rarely, $M$. avium subsp silvaticum (MAS). Despite their close taxonomic relationship, $M$. avium subspecies represent phenotypically diverse organisms, each having a specific pathogenicity and host range characteristics,

\footnotetext{
*Corresponding author: e-mail: vlade@niv.ns.ac.rs
} 
ranging from environmental bacteria that cause opportunistic infections of swine and immunocompromised patients to pathogens of mainly birds and other animals [3]. Identified risk factors for MAC infection in humans include reduced immune competence as a result of HIV infection, immunosuppression associated with cancer, transplantation, pre-existing lung disease and cystic fibrosis [1]. Mycobacteria have been recovered from foodstuffs of various origin. Raw meat or fresh processed, cured, dry fermented and dried meat products in particular play a role as a potential source of MAC for humans [4-6].

In infected animals, $M$. avium may be present in different tissues without apparent clinical symptoms [7,8]. Veterinary meat inspection would then fail to recognize infected animals and such meat and meat products thereof could enter the human diet [4].

This review article deals with analyzing the current control policy in Europe according to infections of pigs with members of MAC and point out of some potential risks for public health.

\section{MAC PREVALANCE IN THE ENVIRONMENT}

M. avium subsp. hominissuis $(M A H)$ is an environmental opportunistic pathogen for humans and swine worldwide [1,2]. The organism is also occasionally isolated from other animals, such as cattle, dogs, birds, deer, horses and wild animals [9-19]. Soil and water are considered to be the natural reservoirs of the organism [20]. MAH can survive in water and within amoeba for up to 26 months [21]. Drinking water and water shower aerosol are thought to be the main sources of MAH infections in humans [2]. In addition the sources of infection for swine include drinking water, feed, bedding materials, soil in pig runs, wastewater, invertebrates and possibly other material [22-26]. Peat as heterogeneous mixture of decomposed plant material (humus) is an important source of MAH, and other NTM that might be of the increasing significance for porcine and human health [1,26-27]. Feces might be of importance for the transmission of $\mathrm{MAH}$ between animals and for the maintenance of the infection pressure in pig herds. Also, pigs might be heavily infected with MAH, although there are no lesions present in their lymph nodes and other organs [27].

The ability of some microorganisms to produce biofilms is probably one of the key features for long-term survival in the environment and the emergence of a possible source of infection form humans and animals was earlier described by different authors [28-31]. M. avium is present in the form of biofilm in the systems of distribution of drinking water. It is assumed that micotil acid can form a hydrophobic matrix and the survival of $M$. avium in the biofilm of these systems is related to the type of material of the plumbing pipes were produced from and the presence of biodegradable materials in the water itself [32]. The formation of biofilms ensures that mycobacteria are present in flowing systems, such as rivers and drinking water distribution systems and 
therefore humans are surrounded by and continually exposed to these opportunists [2].

\section{MAC AND INFECTION IN HUMANS AND PIGS}

MAH is considered clinically the most important MAC member for humans; the organism is a facultative intracellular pathogen for people lacking adequate $\mathrm{T}$ cell immunity. In immunocompetent patients MAH causes, although rarely, pulmonary infections and cervical lymphadenitis, typically in children, and, occasionally, soft tissue infections [31,33]. MAH caused disseminated infections in a high proportion $(25-50 \%)$ of severely immunocompromised AIDS patients [34-35]. After the development of the active antiretroviral therapy, morbidity and mortality caused by $\mathrm{MAH}$ infection in AIDS patients have been greatly reduced and infection rates were stabilized at levels as low as $2.5 \%$ during 2003-2007. Nonetheless, the organism still represents a threat to patients who cannot afford the antiretroviral therapy or when antiretroviral therapy is ineffective [36]. Also, a link between M. avium subsp paratuberculosis (MAP) and Crohn's disease in humans has been widely postulated, but it remains unproven [37-39]. An association between MAP and diabetes mellitus type 1 and multiple sclerosis has also been discussed [40-41]. The subspecies MAA and MAH can cause diverse disseminated infections, tuberculosis-like illnesses, lymphadenitis and osteomyelitis in animals and in humans [4]. MAA and MAH have been the most frequently isolated mycobacterial species from tuberculous lesions in slaughtered pigs and cattle [4,42-43]. Reports on MAH isolates from pigs and humans being closely related [44-48], and the fact that a common source of MAH infection in these two mammalian species is yet to be identified, reinforce the theory generated by the present study that porcine intestinal organs or pork meat can be a potential source of human MAH infection [27].

Studies conducted in countries with large numbers of patients infected with tuberculosis have shown that a BCG vaccine provides an efficient protection for children primarily, but its effect does not last a lifetime [49,50]. The results of a number of studies have revealed that atypical mycobacteria from the environment, including MAC, can affect the reduction in efficiency of BCG vaccine protection [49]. Despite a great number of latently infected, only $10 \%$ of people develop the disease during lifetime and many of them are under the risk of reactivation of tuberculosis in the event of a weakened immune response [51]. This also explains the relation between AIDS and human infection with mycobacteria, having in mind that at the moment more than 15 million people are coinfected with these agents and the immunodeficiency virus [52].

\section{MAC DIAGNOSTICS - MAIN POINTS}

Since mycobacterial infections are asymptomatic in live pigs, the diagnosis is based primarily on gross findings at necropsy combined with histopathological analysis and microbiological culture, followed sometimes by molecular techniques. At rare 
occasions, the results are obtained by using tuberculin skin reaction and gamma interferon probe $[8,53-56]$. The morphological signs of MAC infections are not always macroscopically visible, although granulomas are formed in the tissues as a response to the presence of mycobacteria [54] (Figure 1). Granuloma is a unique tissue-like structure which is a morphological manifestation of the active interaction of an agent and effector cells as part of the immune response of a host to the presence of the agent $[57,58]$. Granulomas in infected pigs are normally located in the local lymphoid tissue of intestines and lymph nodes (Figure 2.) which is why it is common to find lymphadenitis of mandibular (Lnn. mandibulares) and gastrointestinal lymph nodes (Lnn.jejunales, Lnn. ileocolici, i Lnn. colici) on post-mortem examination [8,22,54,59-62]. Similar lesions can be caused by other nonmycobacterial agents, such as Rhodococcus equi, Streptococcus spp., Corynebacterium spp., or various enterobacteria [42,63]. The size of granulomas in pigs infected with Mycobacterium avium subsp. hominissuis (MAH) varies, and the most of granulomas are only visible on microscopic examination [64]. Due to the differences in the size of granulomas, a routine examination of meat in a slaughterhouse could fail to detect specific lesions.

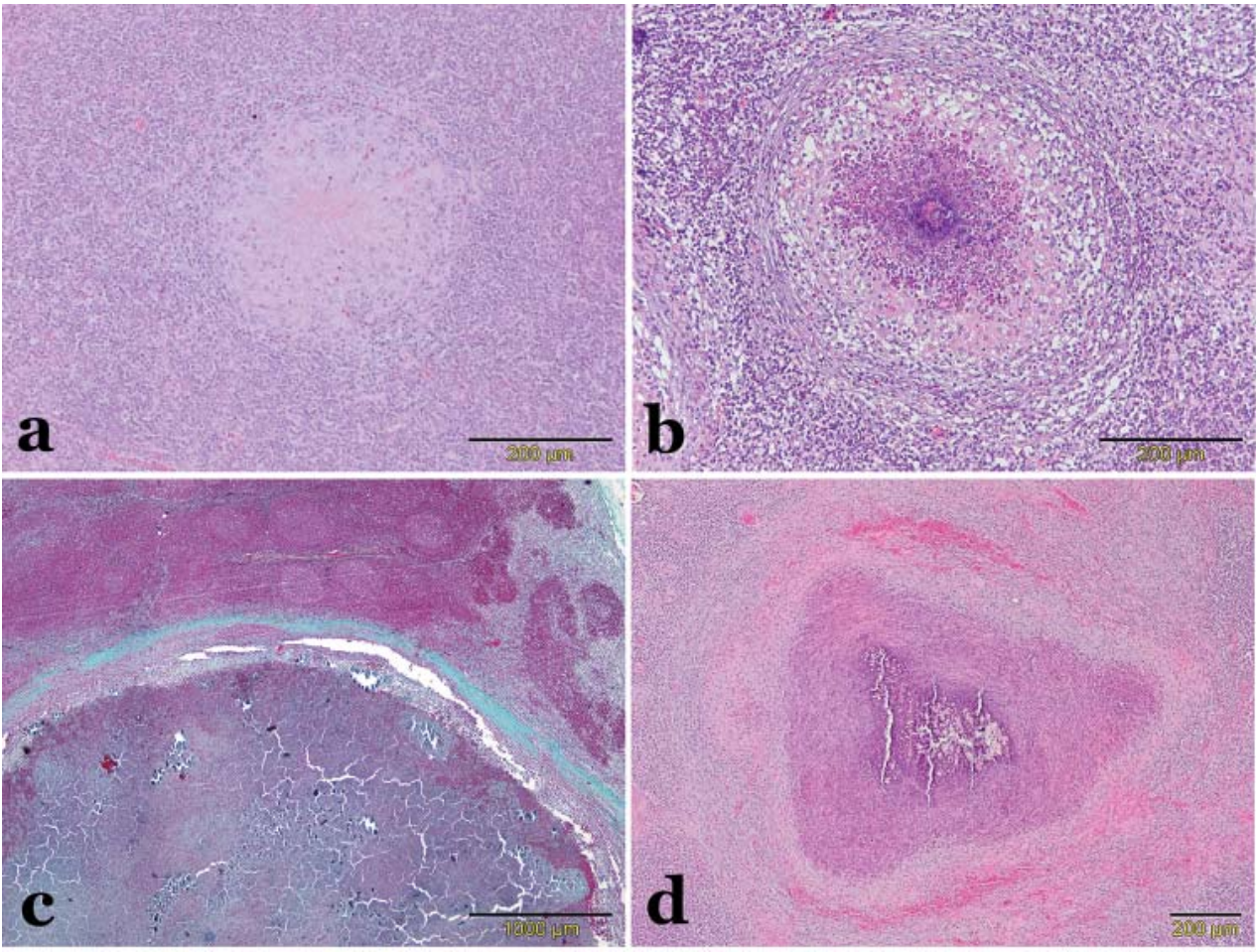

Figure 1. Granuloma in Lnn. jejunales, HE (a,b,d); Connected tissue layer of granuloma, Masson's Trichrome, (c) 

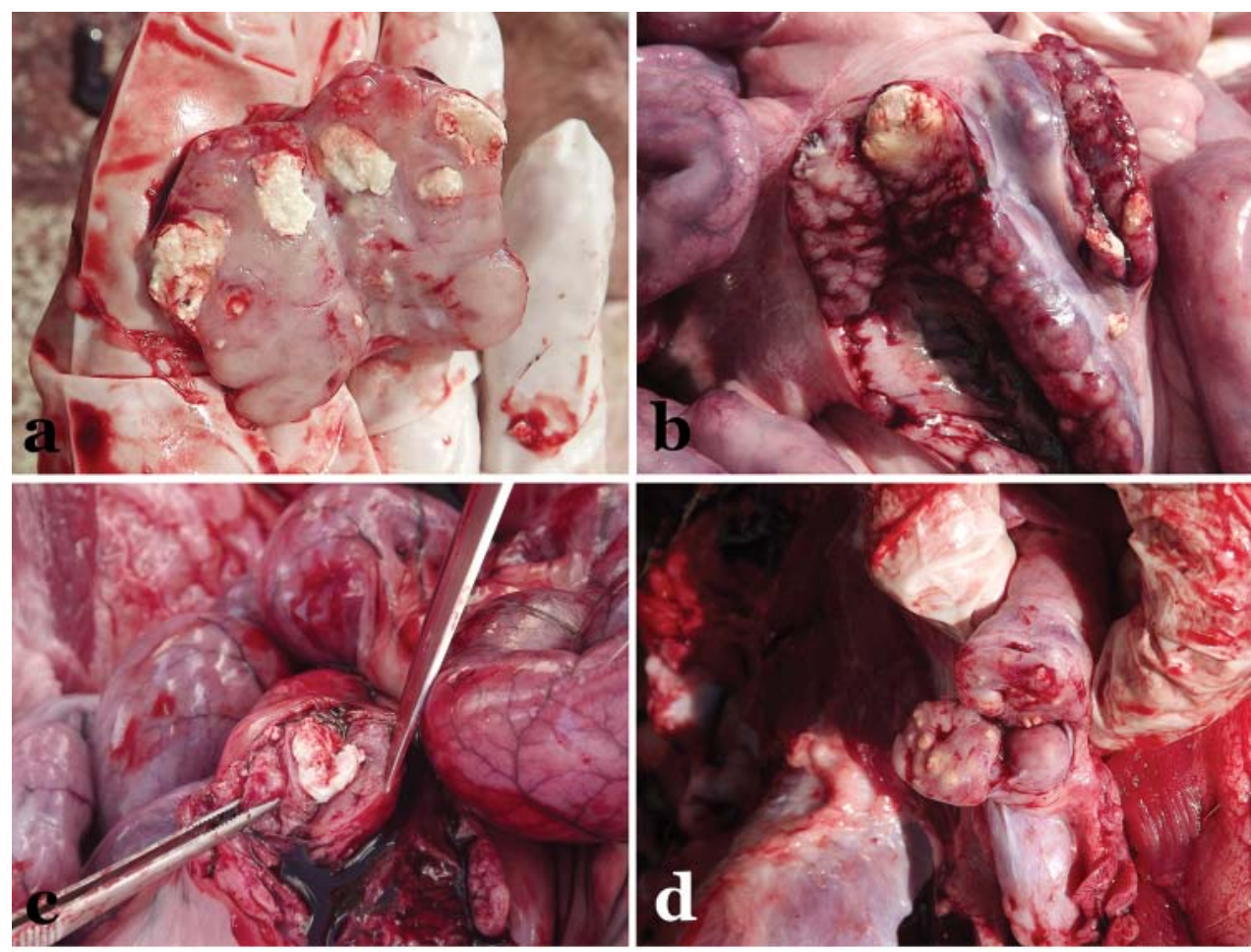

Figure 2. (a-d) Granulomatous lymphadenitis (Mycobacterium avium subsp hominissuis), prominent caseous necrosis and dystrophic calcification in Lnn. jejunales.

Intradermal tuberculin test and gamma interferon tests are the only methods that can be used for live animals. Unfortunately, the use of tuberculin skin test in the majority of EU countries has not been mandatory for many years, while the use of gamma interferon test in swine production is only used mostly for research purposes [56]. Although imperfect, the tuberculin test is a cheap method that has significantly contributed to the eradication of tuberculosis in cattle and consequently in humans [65]. Czech researchers have found that the gamma interferon test provides a greater sensitivity to MAH detection compared with tuberculin test, using only avian tuberculin. Joint research of Norwegian and Serbian researchers has found that the use of bovine and aviary tuberculin increases the detection sensitivity to mycobacteria, including members of MAC. A reaction to both types of tuberculin is common although only MAH was detected $[53,56]$.

Ziebl-Neelsen $(\mathrm{ZN})$ method is a relatively quick and unique technique for the detection of acid fast bacteria, but it cannot determine the specificity of the agent type. Namely, $\mathrm{ZN}$ staining suggests the presence of mycobacteria, but additional microbiological examinations are necessary to exclude other ZN positive microorganisms. This method has its quantitative limitations of mycobacteria detection per slide [66]. Our results obtained when diagnosing mycobacteriosis of breeding pigs imported from 
Austria to Serbia during 2015 have shown that only 3 out of 38 samples of lymph nodes originating from animals positive to simultaneous intradermal test and with visible macroscopic changes on digestive tract lymph nodes were positive according to $\mathrm{ZN}$ method which is slightly less than $7.9 \%$.

In the past it was believed that Ziebl-Neelsen staining method can detect mycobacteria on granuloma periphery. Sakamoto suggests that the highest concentration of acidresistant mycobacteria is in the caseous necrotic center of a granuloma in guinea pigs. Namely, the caseous necrotic content of the granuloma center mostly consists of disintegrated lipid components of host cells. Mycobacteria adapt to this environment by using fatty acids and by thickening their cell walls and thus entering the latent phase [67].

MAC isolation on the culturing mediums is demanding as the agents require specific media (Herrold's eggyolk medium (HEY), modified Middlebrook7H10 and 7H11, modified Lowenstein-Jensen medium (LJ), and it takes 8 weeks [68]. Along with the destruction of other microorganisms, decontamination of samples prior inoculation contributes to the decrease of the number of mycobacteria capable of forming colonies. Our results have shown that cultivation failed after 8 weeks although molecular methods have detected MAH agents [53]. Unlike the methods depending on cultivation of growing media, molecular methods detect DNA of both living and dead mycobacteria or the ones unable to multiply on the culturing media.

Polymerase chain reaction (PCR) allows the detection of very small amounts of DNA and is faster than other diagnostic techniques [69], so the use of PCR to identify pathogens directly from tissues is of major importance for rapid and accurate laboratory confirmation of infectious diseases. However, there are few reports on the identification of MAC species directly from infected tissue without previous microbiological culture [70,71]. Modifications of these methods for the use on paraffin-embedded sections which are of forensic and diagnostic importance have also been described [53].

\section{MAC AND ANIMAL PRODUCTS USED FOR HUMAN CONSUMPTION}

Our results showed that out of 100 examined imported breeding pigs from Lithuania, naturally infected with $\mathrm{MAH}$, which were positive to simultaneous intradermal test to avian tuberculin and/or bovine tuberculin, 43\% had macroscopic changes including caseous necrosis of $\ln n$. jejunales with or without calcification, while in $57 \%$ of the samples no macroscopically visible changes were detected.

Pathohistological examination of this group has revealed characteristic changes in the form of granulomatous lymphadenitis in 45 out of 57 examined samples $(78.94 \%)$. MAH has been confirmed by molecular diagnostics [53,54,64].

These results show that the lesions fail to be detected in the samples of lymph nodes and carcasses examined by post-mortem inspection in slaughterhouses and thus can 
end up in the human food chain. Insufficiently processed products containing MAH are a potential risk for the health of immunocompromised persons and children in particular. The level of mycobacterial contamination of meat products is an important factor contributing to the resulting risk of foodborne diseases in humans. However, detailed information on the mycobacterial contamination level is often missing. One of the reasons is that the cultivation of mycobacteria is time consuming and cumbersome, and often the number of mycobacteria determined using the culture method is underestimated [59].

The results of the research conducted in Portugal by post-mortem examination of lymph nodes and digestive system of pigs in slaughterhouses have shown that the changes are detected in lymph nodes with caseous necrosis or dystrophic calcification and in lymph nodes in the head and mesenteric lymph nodes in $2.15 \%$ of samples (80/3719). PCR assays revealed DNA from the Mycobacterium genus in $41(82 \%)$ out of 50 samples. These were identified as M. avium in 30 samples $(73 \%)$, detected by $16 \mathrm{~S}$ rDNA PCR. Using multiplex PCR, M. avium avium/M. avium silvaticum was detected in 16 samples (39\%) and MAC was found in 24 out of 41 samples (58\%). M. intracellulare and $\mathrm{MAH}$ were not detected [60].

A group of Czech researchers have found that out of 77 analysed meat samples, $17(22 \%)$ contained M. avium subsp. paratuberculosis DNA, $4(5 \%)$ samples contained Mycobacterium avium subsp. avium DNA, and in $12(16 \%)$ samples MAH DNA was detected by qPCR. The concentration of $M$. avium subsp. paratuberculosis and MAH DNA in some meat products exceeded 104 genomes per g. Culture examination of these mycobacterial subspecies was negative. Other studies that examined the presence of mycobacteria in the samples of diaphragm and lymph nodes of slaughtered pigs naturally infected by $M$. avium subsp avium, showed that $M$. a. avium was detected in 20 $(50.0 \%)$ out of 40 pigs. Fifteen (88.2\%) pigs with TB-like lesions in various lymph nodes (LN) were positive to MAA as well as five $(21.7 \%)$ pigs without macroscopic TB-like lesions. A total of $26(24.3 \%)$ tissue samples were positive to MAA by qPCR. The proportion of MAA-positive lymph nodes ( $\mathrm{LN})$ was slightly higher in the head LN (12 [37.5\%]) than in mesenteric LN (7 [22.6\%]). The numbers of MAA cells per $1 \mathrm{~g}$ of sample expressed in orders of magnitude ranged from 103 to 106 in head LN and from 106 to 108 in mesenteric LN of pigs with TB-like lesions. As expected, the proportions of both head and mesenteric LN with MAA, as well as the ranges of MAA cell numbers, were higher in pigs with TB-like lesions. Three diaphragm samples were positive to MAA in pigs with TB-like lesions (102 to 103 MAA cells per $1 \mathrm{~g}$ of sample). Negative qPCR results were obtained from all 23 diaphragms from pigs without TB-like lesions [6].

Kralik et al. studied the survival of $\mathrm{MAH}$ in homemade smoked pork sausages in response to cold $\left(40{ }^{\circ} \mathrm{C}\right.$ for $12 \mathrm{~h}$ ) and hot smoking $\left(70{ }^{\circ} \mathrm{C}\right.$ for $\left.6 \mathrm{~h}\right)$ and after freezing $\left(-20^{\circ} \mathrm{C}\right)$. They did not determine any significant decrease in $\mathrm{MAH}$ count in relation to cold smoking, while no viable MAH cells were detected after hot smoking of sausages. 
The storage of sausages in a freezer resulted in a decrease in viable MAH counts of about 1-3log10. [4].

The study of the presence of NTM in fruit and vegetables conducted by Czech authors has revealed the presence of insertion sequences typical of MAH and MAP. IS900 and IS1245 sequences specific for MAP and MAH were detected only sporadically (more precisely, in three and two samples, respectively). However, their concentrations were only slightly above the detection limit in all cases. The presence of these sequences was not confirmed by culture. Out of the 178 vegetable and fruit samples, 22 mycobacterial isolates were recovered by culture from 17 samples (9.6\%;). Whole vegetables were the most contaminated group, with $18.2 \%$ of mycobacterial isolates and lettuce was the most frequently contaminated vegetable [5].

By analyzing a range of meat samples and other dietary nutrients, different groups of authors have provided evidence to support the hypothesis that $M$. avium is present in everyday commodities sold to the general public [4-6, 60,72-75].

\section{INSUFFICIENT CONTROL - AN UNDERRATED RISK}

Today $M$. avium subspecies are generally not considered food pathogens. Nevertheless, as mentioned previously, the infections caused by nontuberculous mycobacteria can represent a serious threat for immunodeficient persons, children or the elderly. Infections with MAC can affect the efficiency of BCG vaccines used for the human population. This is the only available vaccine for humans $[49,50]$. Therefore, food as a source of infection with mycobacteria should not be ignored.

Mycobacteriosis in pigs quarantined during import from EU countries into the Republic of Serbia is now quite common [53,64]. Thanks to the application of the compulsory comparative intradermal tuberculin test in herds of breeding pigs imported to the Republic of Serbia during the 2007-2015 quarantine period, mycobacteriosis in three herds originating from the EU was detected. The mycobacteriosis was caused by $M$. avium subsp hominissuis (MAH), which was confirmed by molecular diagnostic methods [4]. Due to the presence of these agents, euthanasia of 390 high quality imported pigs was performed and the damage was estimated to be over 250,000 euros (this included direct costs only), which is way more than the cost of implementing the proper control measures for the detection of MAC members. The Republic of Croatia had a similar experience when importing pigs from Austria [55].

The reason for this detection is the application of the compulsory comparative intradermal tuberculin test in herds of breeding pigs during the quarantine period in the Republic of Serbia. Although imperfect, this test still provides satisfactory results in the detection of mycobacteria in the animal population. The fact that some EU regions are MAC free is just an illusion as a result of introduction of visual meat inspection in slaughterhouses, and insufficient use of some of the existing methods of mycobacteria control in live animals (tuberculin skin test and/or gamma interferon test). According to the same documents, EU regions where these agents were detected 
need to introduce additional measures in the process of mycobacteria control in pigs in order to lower the risks for human health and avoid economic losses.

As ESFA suggests, the risk and consequences of the mycobacteria foodborne infections is underrated and often justified by being very low risk $(0.1 \%)$ for meatborne infections. Consequently, according to current EU legislation, in cases of detected localized caseous necrosis only affected lymph nodes and a corresponding organ are condemned - but the carcass is passed as fit for human consumption. For all these reasons, it is considered that omitting incision and palpation of lymph nodes in pigs at routine slaughter could potentially slightly increase public health risk in respect to Mycobacterium spp. but according to this opinion, the risk would still remain low. On the other hand, it is considered that routine incision of lymph nodes may affect food safety, as hazardous cross contamination with e.g. Salmonella spp. and Y. enterocolitica can occur.

Risk assessment in this document is based on extrapolation in a few studies carried out in some EU regions, but due to increasingly scarce measures applied in the control of infections caused by M.avium, it is expected that these figures will be left out. A realistic risk from the infections caused by MAC is inversely proportional in different regions of the EU countries and can be accurately assessed only if all the risks are taken into account from environmental samples, living animals and various products for human consummation with standardized diagnostics in the EU area and neighboring countries.

The control of mycobacteria requires a better diagnostic approach, considering recent positive cases of MAH in an increasing number of imported pigs in quarantines. The introduction of reliable diagnostic methods for $\mathrm{MAH}$ could result in lowering the occurrence of infection in humans. This is particularly important having in mind that the members of the Mycobacterium avium compex could have a negative impact on BCG immunity against $M$. tuberculosis and in synergy with different immunocompromised agents might be a serious threat to human health, which should not be ignored.

\section{Acknowledgement}

This study was supported by TR 31084 and TR 31071 of Ministry of Education, Science and Technological Development, Republic of Serbia. We thank Professor Dejan Krnjaic from the Faculty of Veterinary Medicine, University of Belgrade, for critically reading of the Msc and Marija Kaevska from the Veterinary Institute Brno who provided valuable literature sources.

\section{Authors' contributions}

VP made contributions to conception and design, and acquisition of data and cases as well as final approval of the version to be published. SAK contributed to conception and design, as well as morphological analysis and interpretation of data. She gave 
the final approval of the version to be published. The both of authors agree to be accountable for all aspects of the work in ensuring that questions related to integrity of any part of the work are appropriately resolved.

\section{Declaration of conflicting interests}

The author(s) declared no potential conflicts of interest with respect to the research, authorship, and/or publication of this article.

\section{REFERENCES}

1. Falkinham JO. Surrounded by mycobacteria: Nontuberculous mycobacteria in the human environment. J Appl Microbiol. 2009;107(2):356-67.

2. Falkinham JO. Nontuberculous Mycobacteria: Community and Nosocomial Waterborne Opportunistic Pathogens. Clin Microbiol Newsl. 2016;38(1):1-7.

3. Rindi L, Buzzigoli A, Medici C, Garzelli C. High phylogenetic proximity of isolates of Mycobacterium avium subsp. hominissuis over a two decades-period. Infect Genet Evol. 2013;16:99-102.

4. Klanicova-Zalewska B, Slana I. Presence and persistence of Mycobacterium avium and other nontuberculous mycobacteria in animal tissues and derived foods: A review. Meat Sci. 2014;98(4):835-41.

5. Dziedzinska R, Makovcova J, Kaevska M, Slany M, Babak V, Moravkova M. Nontuberculous Mycobacteria on Ready-to-Eat, Raw and Frozen Fruits and Vegetables. J Food Prot. 2016;79(8):1452-6.

6. Kriz P, Kaevska M, Slana I, Bartejsova I, Pavlik I. Mycobacterium avium subsp. avium in lymph nodes and diaphragms of pigs from one infected herd in the czech republic. J Food Prot. 2014;77(1):141-4.

7. Slana I, Kaevska M, Kralik P, Horvathova A, Pavlik I. Distribution of Mycobacterium avium subsp. avium and M. a. hominissuis in artificially infected pigs studied by culture and IS901 and IS1245 quantitative real time PCR. Vet Microbiol. 2010;144(3-4):437-43.

8. Polaček V, Becskei Z, Vidanović D, Prodanov-Radulović J, Aleksić-Kovačević S. Detection of Mycobacterium avium subsp. hominissuis in lymph nodes with and without gross lesions from tuberculin skin test-positive pigs. J Comp Pathol. 2015 Jan;152(1):83.

9. Kolb J, Hillemann D, Möbius P, Reetz J, Lahiri A, Lewin A, Rüsch-Gerdes S, Richter E. Genetic characterization of German Mycobacterium avium strains isolated from different hosts and specimens by multilocus sequence typing. Int J Med Microbiol. 2014;304(8):9418.

10. Schinköthe J, Möbius P, Köhler H, Liebler-Tenorio EM. Experimental Infection of Goats with Mycobacterium avium subsp. hominissuis: A Model for Comparative Tuberculosis Research. J Comp Pathol. 2015;155(2-3):218-30.

11. Kim M-C, Kim J, Kang W, Jang Y, Kim Y. Systemic infection of Mycobacterium avium subspecies hominissuis and fungus in a pet dog. J Vet Med Sci. 2015;78(1):1-4.

12. Beck A, Špičić S, Butorović-Dujmović M, Račić I, Huber D, Kurilj AG, Beck R, Cvetnić. Mucocutaneous Inflammatory Pseudotumours in Simultaneous Mycobacterium avium subsp. 
avium and Mycobacterium avium subsp. hominissuis Infection in a Cat. J Comp Pathol. 2015 Nov;153(4):227-30.

13. Pate M, Zajc U, Kušar D, Žele D, Vengušt G, Pirš T, Ocepek M. Mycobacterium spp. in wild game in Slovenia. Vet J. 2016;208:93-5.

14. Barthel Y, Drews S, Fehr M, Moser I, Matz-Rensing K, Baumgartner W, Wohlsein P. Concurrent infection with Mycobacterium avium subsp. hominissuis and Giardia duodenalis in a chinchilla (Chinchilla lanigeraf. dom.). Berl Munch Tierarztl Wochenschr. 2016;129(5-6):2426.

15. Kriz P, Jahn P, Bezdekova B, Blahutkova M, Mrlik V, Slana I, Pavlik I. Mycobacterium avium subsp. hominissuis infection in horses. Emerg Infect Dis. 2010;16(8):1328-9.

16. Dagleish MP, Stevenson K, Foster G, McLuckie J, Sellar M, Harley J, Evans J, Brownlow A. Mycobacterium avium subsp. hominissuis Infection in a Captive-Bred Kiang (Equus kiang). J Comp Pathol. 2012;146(4):372-7.

17. Arrazuria R, Sevilla IA, Molina E, Pérez V, Garrido JM, Juste RA, Elguezabal N. Detection of Mycobacterium avium subspecies in the gut associated lymphoid tissue of slaughtered rabbits. BMC Vet Res. 2015;11(1):130.

18. Moravkova M, Mrlik V, Parmova I, Kriz P, Pavlik I. High incidence of Mycobacterium avium subspecies hominissuis infection in a zoo population of bongo antelopes (Tragelaphus eurycerus). J Vet Diagn Invest. 2013;25(4):531-4.

19. Bezos J, Álvarez-Carrión B, Rodríguez-Bertos A, Fernández-Manzano Á, de Juan L, Huguet C, Briones V, Romero B. Evidence of disseminated infection by Mycobacterium avium subspecies hominissuis in a pet ferret (Mustela putorius furo). Vol. 109, Research in Veterinary Science. 2016.

20. Lahiri A, Kneisel J, Kloster I, Kamal E, Lewin A. Abundance of Mycobacterium avium ssp. hominissuis in soil and dust in Germany - implications for the infection route. Lett Appl Microbiol. 2014;59(1):65-70.

21. Vaerewijck MJM, Huys G, Palomino JC, Swings J, Portaels F. Mycobacteria in drinking water distribution systems: ecology and significance for human health. FEMS Microbiol Rev. 2005;29(5):911-34.

22. Matlova L, Dvorska L, Ayele WY, Bartos M, Amemori T, Pavlik I. Distribution of Mycobacterium avium complex isolates in tissue samples of pigs fed peat naturally contaminated with mycobacteria as a supplement. J Clin Microbiol. 2005;43(3):1261-8.

23. Matlova L, Dvorska L, Palecek K, Maurenc L, Bartos M, Pavlik I. Impact of sawdust and wood shavings in bedding on pig tuberculous lesions in lymph nodes, and IS1245 RFLP analysis of Mycobacterium avium subsp. hominissuis of serotypes 6 and 8 isolated from pigs and environment. Vet Microbiol. 2004;102(3-4):227-36.

24. Fischer O A, Matlova L, Dvorska L, Svastova P, Peral DL, Weston RT, Bartos M, Pavlik I. Beetles as possible vectors of infections caused by Mycobacterium avium species. Vet Microbiol. 2004;102(3-4):247-55.

25. Fischer OA, Matlova L, Dvorska L, Svastova P, Bartl J, Weston RT, Pavlik I. Blowflies Calliphora vicina and Lucilia sericata as passive vectors of Mycobacterium avium subsp. avium, M.a. paratuberculosis and M.a. horminissuis. Med Vet Entomol. 2004;18(2):116-22.

26. Johansen TB, Agdestein A, Lium B, Jørgensen A, Djønne B. Mycobacterium avium subsp. hominissuis infection in swine associated with peat used for bedding. Biomed Res Int. 2014;2014:189649. 
27. Agdestein A, Olsen I, Jørgensen A, Djønne B, Johansen TB. Novel insights into transmission routes of Mycobacterium avium in pigs and possible implications for human health. Vet Res. 2014;45:46.

28. Johansen T, Agdestein A, Olsen I, Nilsen S, Holstad G, Djønne B, Turenne C. Biofilm formation by Mycobacterium avium isolates originating from humans, swine and birds. BMC Microbiol. 2009;9(1):159.

29. Milanov D, Prunić B, Velhner M, Todorović D, Polaček V. Investigation of biofilm formation and phylogenetic typing of Escherichia coli strains isolated from milk of cows with mastitis. Acta Vet Belgrade. 2015;65(2):202-16.

30. Čabarkapa I, Škrinjar M, Lević J, Kokić B, Blagojev N, Milanov D, Suvajdžić L. Biofilm forming ability of Salmonella enteritidis in vitro. Acta Vet Belgrade. 2015;65(3):371-89.

31. Faria S, Joao I, Jordao L. General Overview on Nontuberculous Mycobacteria, Biofilms, and Human Infection. J Pathog. 2015;2015:1-10.

32. Johansen TB. Characterisation of Isolates of Mycobacterium avium with emphasis on IS elements and biofilm abilities. The Norwegian School of Veterinary Science; 2009.

33. Rindi L, Garzelli C. Genetic diversity and phylogeny of Mycobacterium avium. Infect Genet Evol. 2014;21:375-83.

34. Inderlied CB, Kemper CA, Bermudez LE. The Mycobacterium avium complex. Clin Microbiol Rev. 1993;6(3):266-310.

35. Falkinham JO. Epidemiology of infection by nontuberculous mycobacteria . Epidemiology of Infection by Nontuberculous Mycobacteria. Clin Microbiol Rev. 1996;9(2):177-215.

36. Karakousis PC, Moore RD, Chaisson RE. Mycobacterium avium complex in patients with HIV infection in the era of highly active antiretroviral therapy. Lancet Infect Dis. 2004;4(9):55765.

37. Bull TJ, Mcminn EJ, Sidi-boumedine K, Skull A, Durkin D, Neild P, Rhodes G, Pickup R, Hermon-taylor J. Detection and Verification of Mycobacterium avium subsp. paratuberculosis in Fresh Ileocolonic Mucosal Biopsy Specimens from Individuals with and without Crohn' s Disease Detection and Verification of Mycobacterium avium subsp. paratuberculosis in Fres. J Clin Microbiol. 2003;41(7):2915-23.

38. Grant IR. Zoonotic potential of Mycobacterium avium ssp. paratuberculosis: The current position. J Appl Microbiol. 2005;98(6):1282-93.

39. Rodrick J. Chiodini, William M. Chamberlin, Jerzy Sarosiek RWM. Crohn's disease and the mycobacterioses: A quarter century later. Causation or simple association? Crit Rev Microbiol. 2012;38(1):52-93.

40. Weller R, Skrypnyk A, Zavgorodniy A, Stegniy B, Gerilovych A, Kutsan O, Pozmogova S, Sapko $S$. The bovine tuberculosis burden in cattle herds in zones with low dose radiation pollution in Ukraine. Vet Ital. 2009;45(2):225-33.

41. Cossu D, Masala S, Frau J, Cocco E, Marrosu MG, Sechi LA. Anti Mycobacterium avium subsp. paratuberculosis heat shock protein 70 antibodies in the sera of Sardinian patients with multiple sclerosis. J Neurol Sci. 2013;335(1):131-3.

42. Lara GHB, Ribeiro MG, Leite CQF, Paes AC, Guazzelli A, Silva AV da, Santos ACB, Listoni FJP. Occurrence of Mycobacterium spp. and other pathogens in lymph nodes of slaughtered swine and wild boars (Sus scrofa). Res Vet Sci. 2011;90(2):185-8.

43. Dvorska L, Matlova L, Bartos M, Parmova I, Bartl J, Svastova P, Bull T., Pavlik I. Study of Mycobacterium avium complex strains isolated from cattle in the Czech Republic between 1996 and 2000. Vet Microbiol. 2004;99(3):239-50. 
44. Ichikawa K, van Ingen J, Koh WJ, Wagner D, Salfinger M, Inagaki T, Uchiya K ichi, Nakagawa T, Ogawa K, Yamada K, Yagi T. Genetic diversity of clinical Mycobacterium avium subsp. hominissuis and Mycobacterium intracellulare isolates causing pulmonary diseases recovered from different geographical regions. Infect Genet Evol. 2015;36:250-5.

45. Pate M, Žolnir-Dovč M, Krt B, Ocepek M. IS1245 RFLP-based genotyping study of Mycobacterium avium subsp. hominissuis isolates from pigs and humans. Comp Immunol Microbiol Infect Dis. 2008;31(6):537-50.

46. Iwamoto T, Nakajima C, Nishiuchi Y, Kato T, Yoshida S, Nakanishi N, Tamaru A, Tamura Y, Suzuki Y, Nasu M. Genetic diversity of Mycobacterium avium subsp. bominissuis strains isolated from humans, pigs, and human living environment. Infect Genet Evol. 2012;12(4):846-52.

47. Ogawa K, Ichikawa K, Hasegawa Y, Inagaki T, Yagi T, Nakagawa T, Moriyama M, Adachi T. Molecular typing and genetic characterization of Mycobacterium avium subspecies hominissuis isolates from humans and swine in Japan. J Med Microbiol. 2016;

48. Starkova DA, Mokrousov IV, Viazovaia AA, Zhuravlev VI, Otten TF, Vishnevskil BI, Narvskaia OV. The genome polymorphism of the Mycobacterium avium subsp. hominissuis strains. Mol Gen Mikrobiol Virusol. 2014;(4):14-9.

49. Andersen P, Doherty TM. The success and failure of BCG-implication for a novel tuberculosis vaccine. Nat Rev Microbiol. 2005;3:657-62.

50. Andersen P. Tuberculosis vaccine- an update. Nat Rev Microbiol. 2007;5:484-7.

51. Graham R, Stewart BDR a. DBY. Tuberculosis: A Problem with Persistence. Nat Rev Microbiol. 2003;1:97-105.

52. Campbell IA. Opportunist (environmental) mycobacterial diseases. Medicine (Baltimore). 2008;36(6):306-8.

53. Agdestein A, Johansen TB, Polaček V, Lium B, Holstad G, Vidanović D, Aleksić-Kovačević S, Jørgensen A, Žultauskas J, Nilsen SF, Djønne B. Investigation of an outbreak of mycobacteriosis in pigs. BMC Vet Res. 2011;7:63.

54. Polaček V, Prodanov-Radulović J, Vidanović D, Kovačević-Aleksić S. Comparision of Macroscopic and Microscopic Lession in Mesenterial Lymph Nodes In Pigs Naturally infected with Mycobacterium avium subsp hominissuis. In: Petrović T, editor. Book of Abstracts “One World New Challenges"-First International Symposium of Veterinary MedicineISVM2015, Vrdnik Serbia. Vrdnik,: Scientific Veterinary Institute Novi Sad, Novi Sad, Serbia; 2015. p. 42-9.

55. Cvetnić Ž, Špičić S, Duvnjak S, Zdelar-Tuk M, Benić M, Mitak M, Pate M, Krt B, Ocepek M. High Prevalence of Mycobacterium avium subsp. hominissuis in a batch of quarantined pigs in Croatia. Slov Vet Res. 2009;46(4):149-54.

56. Faldyna M, Göpfert E, Kudlackova H, Stepanova H, Kaevska M, Slana I, Pavlik I. Usability of a gamma interferon release assay in the diagnosis of naturally infected pigs with Mycobacterium avium subspecies hominissuis. J Vet Diagn Invest. 2012;24(2):376-8.

57. Orme IM, Basaraba RJ. The formation of the granuloma in tuberculosis infection. Semin Immunol. 2014;26(6):601-9.

58. Ulrichs T, Kaufmann SHE. New insights into the function of granulomas in human tuberculosis. J Pathol. 2006;208(2):261-9.

59. Miranda C, Matos M, Pires I, Correia-Neves M, Ribeiro P, Álvares S, Vieira-Pinto M, Coelho AC. Diagnosis of Mycobacterium avium Complex in Granulomatous Lymphadenitis in Slaughtered Domestic Pigs. Vol. 147, Journal of Comparative Pathology. 2012. 
60. Domingos M, Amado a., Botelho a. IS1245 RFLP analysis of strains of Mycobacterium avium subspecies hominissuis isolated from pigs with tuberculosis lymphadenitis in Portugal. Vet Rec. 2009;164(4):116-20.

61. Pate M, Zdovc I, Pirs T, Krt B, Ocepek M. Isolation and characterisation of Mycobacterium avium and Rhodococcus equi from granulomatous lesions of swine lymph nodes in Slovenia. Acta Vet Hung. 2004;52(2):143-50.

62. Sakai M, Ohno R, Higuchi C, Sudo M, Suzuki K, Sato H, Maeda K, Sasaki Y, Kakuda T, Takai S. Isolation of Rhodococcus equi from wild boars (Sus scrofa) in Japan. J Wildl Dis. 2012; 48(3):815-7.

63. Sevilla IA, Molina E, Elguezabal N, Pérez V, Garrido JM, Juste RA. Detection of mycobacteria, Mycobacterium avium subspecies, and Mycobacterium tuberculosis complex by a novel tetraplex real-time PCR assay. J Clin Microbiol. 2015;53(3):930-40.

64. Polaček V. The role of myofibroblast in morphogenesis of granulomatous lymphadenitis in pigs naturally infected with Mycobacterium avium complex. Doctoral Dissertation, Faculty of Veterinary Medicine, University of Belgrade; 2010.

65. Monaghan,M.L., Doherty, M.L., Collins, J.D., Kazda, J.F., Quinn PJ. The tuberculin test. Veterinary Microbiology. 1994;40:111-24.

66. Ulrichs T, Lefmann M, Reich M, Morawietz L, Roth A, Brinkmann V, Kosmiadi GA, Seiler P, Aichele P, Hahn H, Krenn V, Göbel UB, Kaufmann SHE. Modified immunohistological staining allows detection of Ziehl-Neelsen-negative Mycobacterium tuberculosis organisms and their precise localization in human tissue. J Pathol. 2005;205(5):633-40.

67. K. Sakamoto. The Pathology of Mycobacterium tuberculosis Infection. Vet Pathol. 2012;49(3):423-39.

68. Bradner LK. Optimization of methods for culturing Mycobacterium avium subsp. paratuberculosis from bovine milk and colostrum and application to samples collected from naturally infected dairy cows. 2013;

69. Álvarez J, Castellanos E, Romero B, Aranaz a, Bezos J, Rodríguez S, Mateos a, Domínguez L, de Juan L. Epidemiological investigation of a Mycobacterium avium subsp. hominissuis outbreak in swine. Epidemiol Infect. 2011;139(1):143-8.

70. Kaevska M, Slana I, Kralik P, Reischl U, Orosova J, Holcikova A, Pavlik I. “Mycobacterium avium subsp. hominissuis" in neck lymph nodes of children and their environment examined by culture and triplex quantitative real-time PCR. J Clin Microbiol. 2011;49(1):167-72.

71. Slana I, Kaevska M, Kralik P, Horvathova A, Pavlik I. Distribution of Mycobacterium avium subsp. avium and $M$. a. hominissuis in artificially infected pigs studied by culture and IS901 and IS1245 quantitative real time PCR. Vet Microbiol. 2010;144(3-4):437-43.

72. Klanicova B, Slana I, Vondruskova H, Kaevska M, Pavlik I. Real-Time Quantitative PCR Detection of Mycobacterium avium Subspecies in Meat Products. J Food Prot. 2011;74(4):63640.

73. Lorencova A, Vasickova P, Makovcova J, Slana I. Presence of Mycobacterium avium subspecies and hepatitis E virus in raw meat products. J Food Prot. 2014;77(2):335-8.

74. Kaevska M, Lvoncik S, Slana I, Kulich P, Kralik P. Microscopy, culture, and quantitative real-time pcr examination confirm internalization of mycobacteria in plants. Appl Environ Microbiol. 2014;80(13):3888-94.

75. Cvetkovikj I, Mrenoshki S, Krstevski K, Djadjovski I, Angjelovski B, Popova Z, Janevski A, Dodovski A, Cvetkovikj A. Bovine tuberculosis in the Republic of Macedonia: postmortem, microbiological and molecular study in slaughtered reactor cattle. Mac. Vet. Rev. 2017;40(1), doi: 10.1515/macvetrev-2016-0097. 


\title{
MIKOBAKTERIOZA SVINJA - POTCENJENA PRETNJA
}

\author{
POLAČEK Vladimir, ALEKSIĆ-KOVAČEVIĆ Sanja
}

Mada se pripadnici podvrste Mycobacterium avium ne smatraju uzročnicima koji se primarno prenose putem hrane, infekcija ovim netuberkuloznim mikobakterijama (NTM) može predstavljati značajnu pretnju za zdravlje imunokompromitovanih jedinki. Infekcija pripadnicima Mycobacterium avium kompleksa (MAC) može da utiče na BCG imunitet u humanoj populaciji. U inficiranim životinjama M. avium može biti prisutan u različitim organima bez izraženih kliničkih simptoma i morfoloških manifestacija. Iz tog razloga veterinarska inspekcija na liniji klanja nema mogućnost da detektuje inficirane životinje, pa meso i mesni proizvodi od ovih životinja mogu ući u lanac ljudske ishrane. Cilj ovog rada je da iznese i trenutnu politiku kontrole infekcije svinja pripadnicima MAC-a u Evropi, kao i da ukaže na glavne potencijalne rizike. Analizom velikog broja uzoraka mesa i drugih namernica za ljudsku ishranu, različite grupe autora u svojim istraživanjima dokazale su prisustvo $M$. avium, pa se hrana kao izvor infekcije mikobakterijama ipak ne sme zanemariti. Kontrola mikobakterija zahteva bolji dijagnostički pristup, uzimajući u obzir i povećan broj slučajeva infekcija M. avium subsp hominissuis kod svinja koje su se uvozile u Srbiju iz zemalja EU proteklih godina. Uvođenje pouzdanih dijagnostičkih metoda za utvrđivanje MAH uzročnika trebalo bi da smanjenji rizik od infekcije kod svinja, pa i kod ljudi, imajući u vidu da je na osnovu podataka Svetske zdravstvene organizacije registrovano 10 miliona novih slučajeva tuberkuloze odn. mikobakterioze ljudi u toku 2015. godine, a $21 \%$ ovih slučajeva zabeleženo je upravo u populaciji imunokopromitovanih jedinki. 